\title{
KUAT TARIK INTERFASE ANTARA BETON LAMA DAN BETON BARU DENGAN VARIABEL BETON GEOPOLIMER DAN BETON KONVENSIONAL
}

\author{
Purwanto, Rudi Yuniarto Adi, Arum Yumastuti, Farah Diena Amelia \\ Departemen Teknik Sipil, Fakultas Teknik, Universitas Diponegoro \\ purwatrend@gmail.com
}

\begin{abstract}
SCGC Concrete (Self Compacting Geopolymer Concrete) has the advantage of being easier and more effective in casting, so it can be applied to strengthening building structures, including the Concrete Jacketing method and voute / haunch beam. This reinforcement method is a form of composite concrete application with different concrete ages, which consists of existing structures with conventional concrete material and jacket or haunch section with SCGC concrete material. This study aims to determine the characteristics in the form of direct tensile strength, flexural tensile strength, and pull off tests (bond test) to test the strength of adhesion between concrete joints. Making specimens consists of $4 \times 4 \times 16(\mathrm{~cm})$ flexural tensile test beams, and $15 \times 15 \times 60(\mathrm{~cm})$ pull off specimens, and direct tensile specimens in the form of numbers 8 . The principle of making test specimens is done by casting twice The first casting is done on the first half of the mold, then wait until the concrete age is 28 days. Then a second casting is carried out in the next half, until the concrete age is 28 days. So that the total age of concrete in making connection test specimens is 56 days. From the results of this study it was found SCGC concrete has a higher adhesion than conventional concrete so that SCGC concrete can be applied for structural reinforcement.
\end{abstract}

Keywords: geopolymer, flexural, tensile, strength, pulloff

\begin{abstract}
Abstrak
Beton SCGC (Self Compacting Geopolymer Concrete) memiliki keunggulan lebih mudah dan efektif dalam pelaksanaan pengecoran, sehingga diharapkan dapat diterapkan pada perkuatan (strengthening) struktur bangunan, antara lain pada metode beton Jacketing dan balok voute / balok haunch. Metode perkuatan tersebut merupakan bentuk aplikasi beton komposit dengan umur beton yang berbeda, dimana terdiri dari struktur eksisting dengan bahan beton konvensional dan bagian jacket atau haunch dengan bahan beton SCGC. Penelitian ini bertujuan untuk mengetahui karakteristik berupa pengujian kuat tarik langsung, kuat tarik lentur, dan uji pull off (uji bond) untuk menguji kekuatan lekatan antar sambungan beton. Pembuatan benda uji terdiri dari balok uji tarik lentur $4 \times 4 \times 16(\mathrm{~cm})$, benda uji pull off $15 \times 15 \times 60(\mathrm{~cm})$, dan benda uji tarik langsung berbentuk angka 8. Prinsip pembuatan benda uji dilakukan dengan melakukan pengecoran dua kali, pengecoran pertama dilakukan pada setengah bagian cetakan dahulu, kemudian ditunggu sampai umur beton 28 hari. Lalu dilakukan pengecoran kedua pada setengah bagian selanjutnya, sampai umur beton 28 hari. Sehingga total umur beton dalam pembuatan benda uji sambungan adalah 56 hari. Dari hasil penelitian ini didapatkan bahwa beton SCGC memiliki lekatan yang lebih tinggi dibanding beton konvensional sehingga beton SCGC dapat diaplikasikan untuk perkuatan struktur.
\end{abstract}

Kata kunci: geopolimer, kuat, tarik, lentur, tarikcabut

\section{PENDAHULUAN}

Beton geopolimer SCGC (Self

Compacting Geopolymer Concrete) adalah

beton berbahan dasar fly ash tipe $F$, dimana

harus memenuhi kriteria kelecakan beton

memadat sendiri. Kriteria workability dari self

compacting concrete adalah kemampuan campuran beton untuk mengisi ruangan, melewati struktur ruangan yang rapat, dan ketahanan campuran beton segar terhadap efek segregasi (EFNARC, 2005).

Pada penelitian Al Faridy dan Ninda (2019) telah menguji pengaruh kadar semen, extra water dan kadar superplastizer pada nilai 
workability beton geopolimer. Pada penelitian ini digunakan larutan alkali aktivator campuran larutan $\mathrm{NaOH} 12 \mathrm{M}$ dan $\mathrm{Na}_{2} \mathrm{SiO}_{3}$ Be58. Natrium Silikat berfungsi untuk mempercepat reaksi polimerisasi, sedangkan Natrium Hidroksida berfungsi untuk mereaksikan unsurunsur Al dan Si yang terkandung dalam fly ash sehingga dapat menghasilkan ikatan polimer yang kuat. Hasil penelitian menunjukan nilai slump flow antara $20-30 \mathrm{~cm}$ dengan mutu kuat tekan beton sedang.

Pada penelitian kami, digunakan larutan alkali aktivator dari campuran larutan $\mathrm{NaOH} 12$ $\mathrm{M}$ dan Natrium Silikat $\left(\mathrm{Na}_{2} \mathrm{SiO}_{3}\right)$ tipe Be52. $\mathrm{Na}_{2} \mathrm{SiO}_{3}$ Be52 mengandung $\mathrm{Na}_{2} \mathrm{O}$ 14,55\%, $\mathrm{SiO}_{2} \quad 33,76 \%$, di mana dalam proses pembentukan garamnya (kristalisasi) menggunakan konsentrasi sebesar $52 \mathrm{Be}$. Notasi Be merupakan derajat pada skala pengukuran dengan menggunakan baumemeter. $\mathrm{Na}_{2} \mathrm{SiO}_{3}$ Be52 mempunyai sifat fisik lebih cair dibandingkan $\mathrm{Na}_{2} \mathrm{SiO}_{3} \mathrm{Be} 58$, karena dalam pembuatan $\mathrm{Na}_{2} \mathrm{SiO}_{3}$ Be52 menggunakan larutan $\mathrm{NaOH}$ lebih banyak. Dengan sifat fisik yang lebih cair diharapkan menghasilkan campuran beton geopolimer SCGC. Pada penelitian ini nilai rasio perbandingan $\mathrm{NaOH} 12 \mathrm{M}$ dan $\mathrm{Na}_{2} \mathrm{SiO}_{3} \mathrm{Be} 52$ yang digunakan adalah $1: 2,5$.

Strengthening pada struktur bangunan diperlukan apabila terjadi kerusakan yang menyebabkan degradasi kekuatan yang berakibat tidak terpenuhi persyaratanpersyaratan yang bersifat teknik yaitu strength, stiffness dan daktilitas, kestabilan, serta ketahanan terhadap kinerja tertentu (Triwiyono, 1998). Pada penelitian oleh Tudjono et al. (2015) telah mengkaji perkuatan balok dengan bahan FRP (Fibre Reinforced Polymer) dan menguji pengaruh kekasaran permukaan beton terhadap lekatan akibat tarik dan geser antara FRP dengan beton eksisting. Perlakuan kekasaran ada beberapa tipe diantaranya tipe longitudinal, transversal, diagonal, cross dan tipe polos.

Pada penelitian ini, akan mengkaji penerapan beton geopolimer SCGC (Self Compacting Geopolymer Concrete) sebagai bahan untuk perkuatan struktur dengan metode balok haunch. Metode stregthening tersebut merupakan bentuk aplikasi beton komposit dengan umur beton yang berbeda, dimana terdiri dari struktur existing dengan beton konvensional dan bagian strengthening dengan beton geopolimer SCGC.

Untuk mengevaluasi kekuatan pada lekatan interfase sambungan, pada penelitian ini dilakukan pengujian kuat tarik langsung, kuat tarik tidak langsung, dan uji pull off (uji bond) dengan membandingkan bagaimana sifat teknis dan perilaku elemen struktural tersebut pada sambungan beton konvensional dengan beton geopolimer, sambungan antar sesama beton geopolimer, serta sambungan antar sesama beton konvensional.

\section{TINJAUAN PUSTAKA}

Benda uji dibuat dimulai dari pemeriksaaan bahan material hingga proses perawatan atau curing. Prosedur pembuatan benda uji dilakukan dengan langkah-langkah berikut:

1. Pemeriksaan agregat halus dan agregat kasar yang meliputi:

a. Pengujian kadar lumpur (PBI 1971)

b. Pengujian kadar zat organik (ASTM C40)

c. Pengujian kadar air (SNI 03-1737-1989)

d. Pengujian berat jenis (SNI 03-17371989)

e. Pengujian berat isi (ASTM C33)

f. Pengujian gradasi agregat (ASTM C33)

2. Mix design atau campuran beton dengan standar mutu beton normal. Komposisi campuran beton konvensional yaitu sebagai berikut:
a. Agregat : Binder
$=70 \%: 30 \%$
b. Sand : agregat kasar
$=40 \%: 60 \%$
c. Semen : Air
$=65 \%: 35 \%$

Pembuatan beton geopolimer SCGC (Self- Compacting Geopolymer Concrete) pada penelitian ini disyaratkan memenuhi standar beton normal. Mix design yang digunakan sebagai berikut:
a. Agregat: $($ binder + AA) $=70 \%: 30 \%$
b. Sand: agregat kasar $\quad=40 \%: 60 \%$
c. Binder: AA $\quad=65 \%: 35 \%$
d. $\mathrm{NaOH}(12 \mathrm{M}): \mathrm{Na}_{2} \mathrm{SiO}_{3} \mathrm{Be} 52=1: 2,5$
e. Semen $\quad=5,63 \%$ dari fly ash
f. Air $\quad=11,7 \%$ dari fly ash
g. Masterglenium Sky $8851=2 \%$ dari FA Metode Pembuatan Beton
Geopolimer mengacu pada hasil dari 
penelitian sebelumnya (Al Faridy dan Ninda, 2019) yaitu:

a. Menimbang semua material yang digunakan untuk pengecoran sesuai dengan mix design (fly ash, agregat halus, agregat kasar, larutan alkali, semen, dan superplasticizer) dan mempersiapkan seluruh alat yang akan digunakan (cetakan benda uji, loyang, tongkat penumbuk, kerucut abrams, mesin penggetar, cetok, dan lain-lain).

b. Mencampur agregat kasar dan binder (fly ash ditambah semen) hingga tercampur dengan rata.

c. Menuang larutan alkali aktivator dan superplasticizer pada campuran agregat kasar dan binder.

d. Tunggu hingga beberapa menit sehingga semua terlapisi aktivator dan adonan terlihat mengkilap. Setelah itu dimasukkan agregat halus dan air kemudian diaduk hingga semuanya rata (homogen).

3. Pengujian slump menggunakan kerucut Abram ukuran diameter bawah $200 \mathrm{~mm}$, diameter atas $100 \mathrm{~mm}$, dan tinggi $300 \mathrm{~mm}$. Untuk beton geopolimer dilakukan pengujian nilai slump secara horizontal untuk mengetahui workability dari campuran beton geopolimer. Nilai slump horizontal untuk beton SCGC (Self Compacting Geopolymer Concrete), yaitu 550 - 850 mm (EFNARC, 2005), sedangkan untuk beton konvensional dilakukan uji slump vertikal.

4. Pembuatan sample silinder untuk pengujian karakteristik beton geopolimer dan beton konvensional berupa kuat tekan yang dilakukan pada umur 7 dan 28 hari menggunakan silinder $15 \times 30(\mathrm{~cm})$ dan silinder $10 \times 20(\mathrm{~cm})$.

5. Pembuatan Benda Uji, meliputi: Benda Uji Tarik Langsung Angka 8 (Gambar 1), Benda Uji Tarik Lentur (Gambar 2), dan Benda Uji Pull Off (Gambar 3). Pembuatan benda uji terdiri dari balok uji tarik lentur dengan dimensi $4 \times 4 \times 16(\mathrm{~cm})$ sebanyak 9 buah, benda uji pull off dimensi $15 \times 15 \times 60$ (cm) sebanyak 4 buah, dan benda uji tarik langsung berbentuk angka 8 sebanyak 9 buah. Benda uji berupa sambungan antara Beton Konvensional dan Beton Geopolimer $(B K+B G)$, Sambungan antar Beton Geopolimer (BG + BG), dan sambungan antar Beton Konvensional (BK + BK). Prinsip pembuatan benda uji dilakukan dengan melakukan pengecoran dalam dua tahapan, dimana pengecoran pertama hanya dilakukan pada setengah bagian cetakan terlebih dahulu, yang kemudian ditunggu sampai umur beton 28 hari. Lalu dilakukan pengecoran kedua pada setengah bagian selanjutnya, sampai umur beton 28 hari. Sehingga total umur beton dalam pembuatan benda uji sambungan adalah 56 hari.
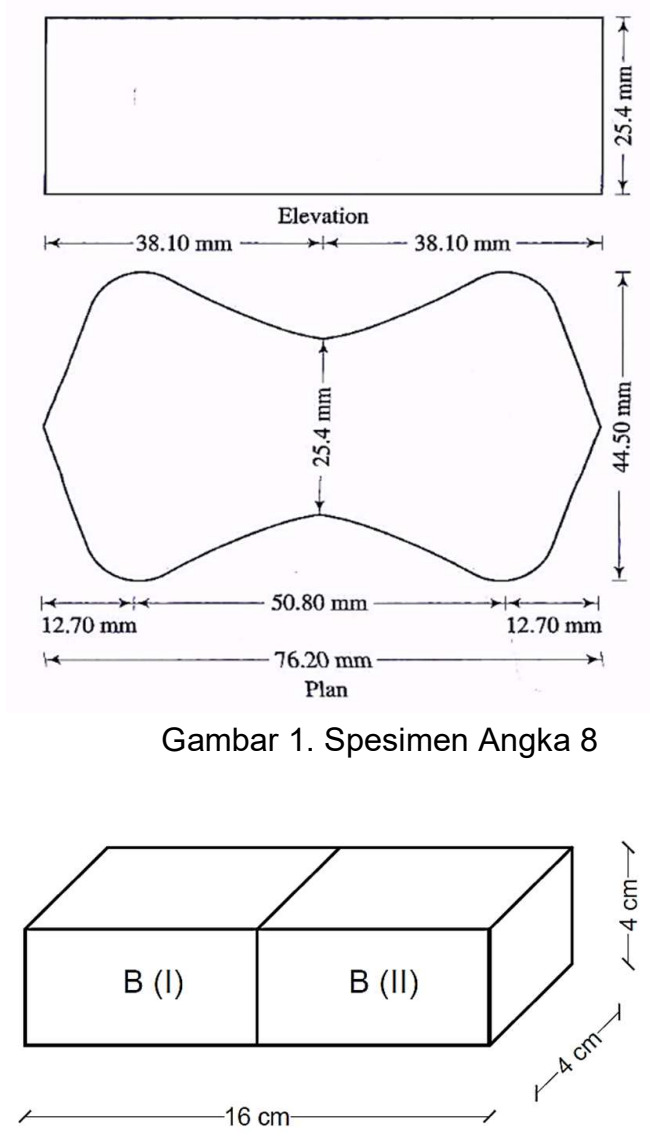

Gambar 2. Spesimen Uji Tarik Lentur 


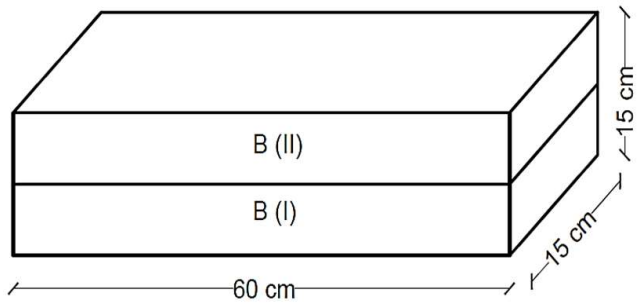

Gambar 3. Dimensi Benda Uji Pull Off

\section{METODE PENELITIAN}

Metode curing yang digunakan pada Benda Uji Tarik Langsung, Tarik Lentur, Pull Off pada setengah bagian dengan bahan beton konvensional serta sampel silinder yaitu dengan cara direndam dalam air (Gambar 4). Pada benda uji dengan bahan beton geopolimer curing dilakukan dengan menggunakan karung goni basah (Gambar 5).

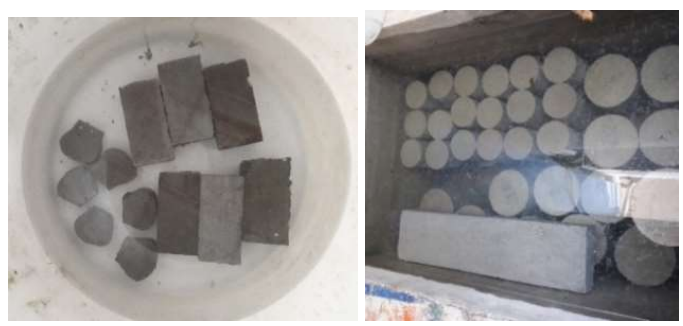

Gambar 4. Curing direndam dalam air

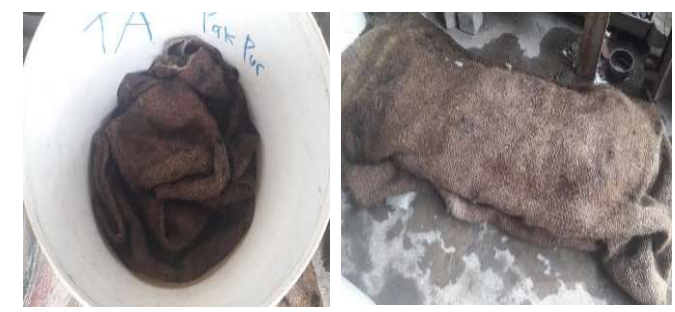

Gambar 5. Curing dengan Karung Goni

Benda Uji yang sudah di curing dengan umur beton 56 hari, dikeringkan dengan cara diangin-anginkan. Metode pengujian setiap benda uji berdasarkan Code :

\section{Metode Uji Tarik Langsung (ASTM C307, 2003)}

a. Meletakan benda uji angka 8 pada alat uji tarik langsung.

b. Lakukan Pembebanan sampai benda uji menjadi hancur dan catat beban maksimum yang terjadi selama pemeriksaan.

c. Melakukan dokumentasi benda uji untuk menganalisis bentuk pecah dan kondisi setelah selesai pengujian. Set up pengujian sesuai Gambar 6 .

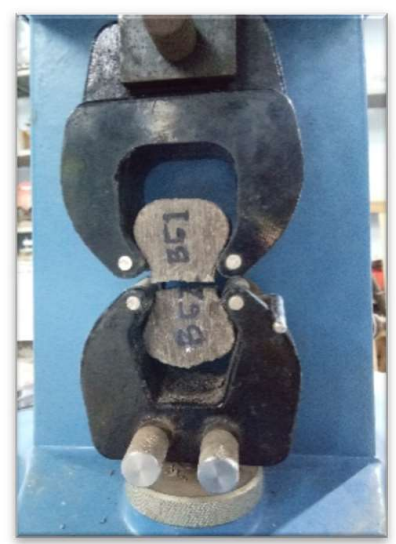

Gambar 6. Set up Pengujian Tarik Langsung

\section{Metode Uji Kuat Tarik Lentur (SNI 03-4154, 2014)}

a. Menyiapkan benda uji dan memastikan dalam kondisi kering dan bersih.

b. Mengukur panjang kedua sisi balok.

c. Mengukur dan memberi tanda menggunakan kapur pada bagian tengah benda uji.

d. Menimbang benda uji dan kemudian membaca hasil timbangan.

e. Meletakan benda uji pada dua tumpuan.

f. Meletakan beban ditengah-tengah bentang posisi $1 / 2 \mathrm{~L}$.

g. Menyalakan mesin sehingga jarum skala bergerak perlahan-lahan sampai benda uji patah, dimana kecepatan harus diatur dan dijaga konstan.

h. Baca beban maksimum patah dan catat pada formulir.

i. Pengujian benda uji dilakukan dengan alat Compression Test Machine (Hung Ta HT-8391PC Computer-Controlled Servo Hydraulic). Set up pengujian sesuai Gambar 7. 


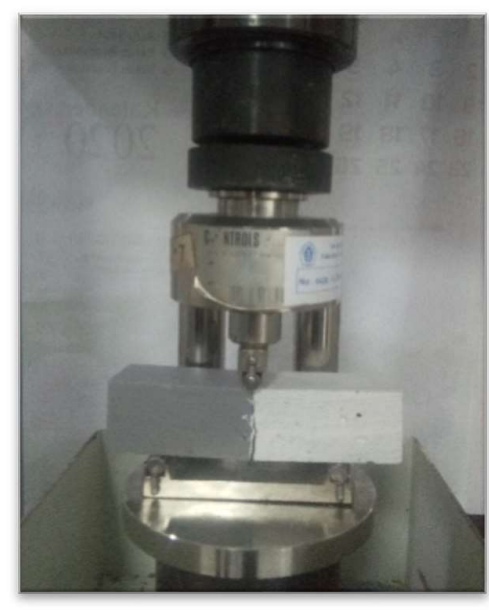

Gambar 7. Set up Pengujian Tarik Lentur

Metode Uji Pull Off (ASTM C1583, 2013)

a. Dengan menggunakan peralatan coring, bor sebuah potongan melingkar tegak lurus permukaan. Untuk tes bahan overlay, bor setidaknya $0.5 \mathrm{~mm}$ di bawah antarmuka beton-overlay. Spesimen uji dibiarkan utuh melekat pada substrat.

b. Ukur diameter tes dalam dua arah, lalu diambil rata-ratanya.

c. Buang semua genangan air, bersihkan permukaan dari sisa-sisa pengeboran dan biarkan kering.

d. Pasang pelat baja ke bagian atas benda uji menggunakan perekat epoksi. Pastikan disk baja terpusat pada benda uji. e. Pasang perangkat tarik ke disk baja.

f. Berikan beban tarik pada benda uji.

g. Terapkan beban tarik pada laju konstan sehingga tegangan tarik meningkat pada kecepatan $35+15$ $\mathrm{kPa} / \mathrm{s}$.

h. Catat besarnya beban saat terjadi kerusakan.

i. Hitung kekuatan tarik dengan persamaan. Set up pengujian sesuai dengan Gambar 8.

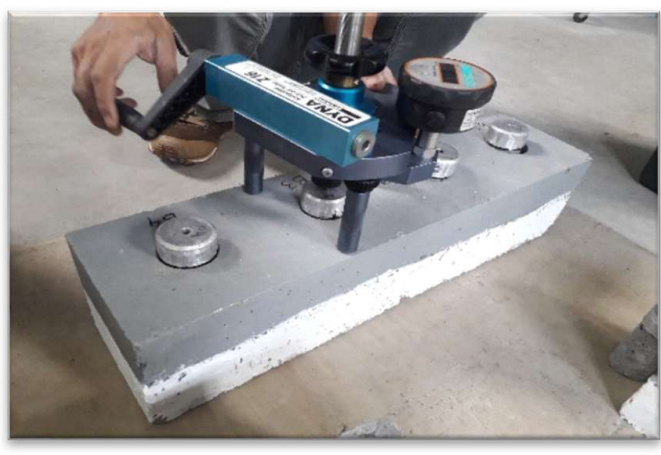

Gambar 8. Set up Pengujian Pull Off

\section{HASIL DAN PEMBAHASAN}

Pengujian bahan material bertujuan untuk mengidentifikasi karakteristik material sesuai dengan standard yang berlaku yang selanjutnya akan digunakan dalam campuran beton SCGC (Self Compacting Geopolymer Concrete). Hasil pengujian material ditampilkan pada Tabel 1.

Tabel 1. Hasil Analisa Pengujian Material

\begin{tabular}{|l|c|c|c|c|}
\hline & \multicolumn{2}{|c|}{ Agregat Halus } & \multicolumn{2}{c|}{ Agregat Kasar } \\
\hline & Asli & SSD & \multicolumn{2}{c|}{ Asli } \\
\hline
\end{tabular}

Tabel 2. Hasil Pengujian Kuat Tekan Beton Konvensional

\begin{tabular}{|c|c|c|c|c|c|c|}
\hline No & $\begin{array}{l}\text { Diameter } \\
(\mathrm{mm})\end{array}$ & $\begin{array}{l}\text { Tinggi } \\
(\mathbf{m m})\end{array}$ & $\begin{array}{l}\text { Luas } \\
\text { penampang } \\
\left(\mathrm{mm}^{2}\right)\end{array}$ & $\begin{array}{l}\text { Beban Max } \\
\text { (N) }\end{array}$ & $\begin{array}{l}\text { Kuat tekan } \\
\text { f'c (MPa) }^{-}\end{array}$ & $\begin{array}{l}\text { Rata- } \\
\text { rata } \\
\text { (MPa) }\end{array}$ \\
\hline 1.1 & 150 & 300 & $17.678,6$ & 550.000 & 31,11 & \multirow{3}{*}{31,11} \\
\hline 1.2 & 150 & 300 & $17.678,6$ & 500.000 & 28,28 & \\
\hline 1.3 & 150 & 300 & $17.678,6$ & 600.000 & 33,94 & \\
\hline 2.1 & 150 & 300 & $17.678,6$ & 570.000 & 32,24 & \multirow{2}{*}{32,52} \\
\hline 2.2 & 150 & 300 & $17.678,6$ & 580.000 & 32,81 & \\
\hline
\end{tabular}


Tabel 3. Hasil Pengujian Kuat Tekan Beton Geopolimer

\begin{tabular}{|c|c|c|c|c|c|c|}
\hline No & $\begin{array}{l}\text { Diameter } \\
(\mathrm{mm})\end{array}$ & $\begin{array}{l}\text { Tinggi } \\
\text { (mm) }\end{array}$ & $\begin{array}{l}\text { Luas } \\
\text { penampang } \\
\left(\mathrm{mm}^{2}\right)\end{array}$ & $\begin{array}{l}\text { Beban } \\
\operatorname{Max}(\mathbf{N})\end{array}$ & $\begin{array}{l}\text { Kuat } \\
\text { tekan f'c } \\
\text { (MPa) }\end{array}$ & $\begin{array}{l}\text { Rata- } \\
\text { rata } \\
\text { (MPa) }\end{array}$ \\
\hline 1.1 & 150 & 300 & $17.678,6$ & 560.000 & 31,68 & \multirow{3}{*}{31,49} \\
\hline 1.2 & 150 & 300 & $17.678,6$ & 570.000 & 32,24 & \\
\hline 1.3 & 150 & 300 & $17.678,6$ & 540.000 & 30,55 & \\
\hline
\end{tabular}

Pengujian kuat tekan beton dilakukan setelah perawatan dengan waktu 28 hari. Hasil pengujian kuat tekan beton silinder dapat dilihat pada Tabel 2 dan Tabel 3. Kuat tekan rata-rata beton yang dihasilkan dari pengujian di Laboratorium Bahan dan Konstruksi Departemen Teknik Sipil, Fakultas Teknik UNDIP sudah memenuhi rencana beton mutu sedang berdasarkan Pd T-07-2005-B. Sependapat dengan riset (Qomaruddin dan Sudarno, 2019) yang melaminasi beton geopolimer dan konvensional terhadap kuat tekannya pada kubus.
Syarat nilai slump untuk beton SCC (Self Compacting Concrete) menurut EFNARC (2005) yaitu antara $550-850 \mathrm{~mm}$. Nilai slump yang didapat pada penelitian ini yaitu 600 $650 \mathrm{~mm}$.

Hasil pengujian kuat tarik langsung ditampilkan pada Tabel 4. Dari tabel tersebut dapat dilihat bahwa sambungan BG - BG memiliki kuat tarik langsung paling tinggi dengan nilai rata-rata sebesar $2.377 \mathrm{MPa}$. Perbandingan kekuatan antara sambungan BG-BG : BK-BG : BK-BK yaitu $1: 0.84: 0.67$.

Tabel 4. Hasil Pengujian Kuat Tarik Langsung Beton

\begin{tabular}{|c|c|c|c|c|c|c|}
\hline Kode & $\begin{array}{l}\text { Total } \\
\text { Umur }\end{array}$ & Berat (kg) & $\begin{array}{c}\text { Gaya } \\
(\mathbf{k N})\end{array}$ & $\begin{array}{l}\text { Luas } \\
\left(\mathrm{mm}^{2}\right)\end{array}$ & $\begin{array}{c}\text { Kuat Tarik } \\
\text { (MPa) }\end{array}$ & $\begin{array}{c}\text { Rata-rata } \\
\text { (MPa) }\end{array}$ \\
\hline BG - BG & 49 & 0,14340 & 1,56 & 645,16 & 2,418 & \multirow{3}{*}{2,377} \\
\hline BG - BG & 49 & 0,14665 & 1,58 & 645,16 & 2,449 & \\
\hline BG - BG & 49 & 0,15055 & 1,46 & 645,16 & 2,263 & \\
\hline BK - BG & 49 & 0,15155 & 1,19 & 645,16 & 1,845 & \multirow{3}{*}{1,994} \\
\hline BK - BG & 49 & 0,15060 & 1,39 & 645,16 & 2,155 & \\
\hline BK - BG & 49 & 0,15060 & 1,28 & 645,16 & 1,984 & \\
\hline BK - BK & 48 & 0,15060 & 1,08 & 645,16 & 1,674 & \multirow{3}{*}{1,591} \\
\hline BK - BK & 48 & 0,14710 & 1,05 & 645,16 & 1,628 & \\
\hline BK - BK & 48 & 0,15020 & 0,95 & 645,16 & 1,473 & \\
\hline
\end{tabular}

Tabel 5. Hasil Pengujian Kuat Tarik Tidak Langsung / Lentur Beton

\begin{tabular}{|c|c|c|c|c|c|c|c|}
\hline Kode & $\begin{array}{l}\text { Umur } \\
\text { (Hari) }\end{array}$ & $\begin{array}{c}\text { b } \\
(\mathrm{mm})\end{array}$ & $\begin{array}{c}d \\
(\mathrm{~mm})\end{array}$ & $\begin{array}{c}\mathrm{L} \\
(\mathrm{mm})\end{array}$ & $\begin{array}{c}\text { Max Force } \\
\text { (N) }\end{array}$ & $\begin{array}{l}\text { Kuat Lentur } \\
\text { (MPa) }\end{array}$ & $\begin{array}{c}\text { Rata - rata } \\
\text { (MPa) }\end{array}$ \\
\hline BG - BG & 63 & 40 & 40 & 120 & $1.584,20$ & 4,46 & \multirow{3}{*}{4,56} \\
\hline BG - BG & 63 & 40 & 40 & 120 & $1.746,46$ & 4,91 & \\
\hline BG - BG & 63 & 40 & 40 & 120 & $1.528,69$ & 4,30 & \\
\hline BK - BG & 63 & 40 & 40 & 120 & $1.195,62$ & 3,36 & \multirow{3}{*}{3,46} \\
\hline BK - BG & 63 & 40 & 40 & 120 & $1.229,78$ & 3,46 & \\
\hline BK - BG & 63 & 40 & 40 & 120 & $1.268,21$ & 3,57 & \\
\hline BK -BK & 62 & 40 & 40 & 120 & 841,20 & 2,37 & \multirow{3}{*}{2,76} \\
\hline BK -BK & 62 & 40 & 40 & 120 & $1.016,28$ & 2,86 & \\
\hline BK -BK & 62 & 40 & 40 & 120 & $1.084,60$ & 3,05 & \\
\hline
\end{tabular}


Tabel 6. Hasil Pengujian Kuat Cabut (Pull-off) Beton

\begin{tabular}{|c|c|c|c|c|c|c|c|}
\hline Kode & $\begin{array}{l}\text { Umur } \\
\text { (Hari) }\end{array}$ & $\begin{array}{l}\text { Diameter } \\
(\mathrm{mm})\end{array}$ & $\begin{array}{l}\text { Luas } \\
\left(\mathrm{mm}^{2}\right)\end{array}$ & Gaya (N) & $\begin{array}{c}\text { Kuat } \\
\text { Tarik } \\
\text { (MPa) }\end{array}$ & $\begin{array}{l}\text { Rata- } \\
\text { rata } \\
\text { (MPa) }\end{array}$ & $\begin{array}{l}\text { Keterangan } \\
\text { (daerah } \\
\text { kegagalan) }\end{array}$ \\
\hline BG -BG & 79 & 50 & $1.964,29$ & $3.452,64$ & 1,76 & \multirow{4}{*}{1,62} & sambungan \\
\hline BG -BG & 79 & 50 & $1.964,29$ & $2.469,96$ & 1,26 & & sambungan \\
\hline BG -BG & 79 & 50 & $1.964,29$ & $3.532,31$ & 1,80 & & BG \\
\hline BG -BG & 79 & 50 & $1.964,29$ & $3.266,73$ & 1,66 & & BG \\
\hline BK - BG & 75 & 50 & $1.964,29$ & $2.868,35$ & 1,46 & \multirow{4}{*}{1,39} & sambungan \\
\hline BK - BG & 75 & 50 & $1.964,29$ & $2.363,73$ & 1,20 & & sambungan \\
\hline BK - BG & 75 & 50 & $1.964,29$ & $2.788,67$ & 1,42 & & BG \\
\hline$B K-B G$ & 75 & 50 & $1.964,29$ & $2.868,35$ & 1,46 & & $B G$ \\
\hline BK - BK & 78 & 50 & $1.964,29$ & $1.832,55$ & 0,93 & 0,93 & sambungan \\
\hline BK - BK & 78 & 50 & $1.964,29$ & & & & coring \\
\hline BK - BK & 78 & 50 & $1.964,29$ & & & & coring \\
\hline BK - BK & 78 & 50 & $1.964,29$ & & & & coring \\
\hline
\end{tabular}

Hasil pengujian kuat tarik tidak langsung / lentur ditampilkan pada Tabel 5. Dari tabel tersebut dapat dilihat bahwa sambungan BG BG memiliki kuat lentur paling tinggi dengan rata-rata sebesar $4.56 \mathrm{MPa}$. Perbandingan kekuatan antara sambungan BG-BG : BK-BG : BK-BK yaitu $1: 0.76: 0.60$. Hasil Pengujian kuat tarik cabut (Pull-off) ditampilkan pada Tabel 6. Dari tabel tersebut dapat dilihat bahwa sambungan BG - BG memiliki kuat cabut paling tinggi dengan rata-rata sebesar 1.62 $\mathrm{MPa}$. Perbandingan kekuatan antara sambungan BG-BG : BK-BG : BK-BK yaitu 1 : $0.86: 0.57$.

\section{Hubungan Kuat Tekan dan Kuat Tarik Beton}

Berdasarkan hasil analisis yang telah dilakukan maka kuat tekan dan kuat tarik beton dapat dibandingkan seperti pada Tabel 7. Ada beberapa pendekatan yang dilakukan untuk mencari hubungan antara kuat tekan dan kuat tarik beton, yaitu:

- SNI 03-2847-2013: $f_{c t}=0.33 \sqrt{f^{\prime}}{ }_{c} \mathrm{MPa}$
- $\mathrm{BS}$ 8007-1987 : $f_{c t}=0.12{f^{\prime}}_{c}{ }^{0.7} \mathrm{MPa}$

- SNIT-15-1991-03: $f_{c t}=0.70 \sqrt{f^{\prime}{ }_{c}} \mathrm{MPa}$

- $\mathrm{ACl} 318: f_{c t}=0.56 \sqrt{f^{\prime}{ }_{c}} \mathrm{MPa}$

- SNI 03-2847: 2013: $f_{c t}=0.56 \sqrt{f^{\prime}{ }_{c}} \mathrm{MPa}$

- Dipohosodo, $1999: f_{c t}=0.57 \sqrt{f^{\prime}}{ }_{c} \mathrm{MPa}$

- Raphael, $1984: f_{c t}=0.313 f^{\prime}{ }_{c}{ }^{0.667} \mathrm{MPa}$

- Selim, $2008: f_{c t}=0.106 f^{\prime}{ }_{c}{ }^{0.948} \mathrm{MPa}$

Untuk mencari persamaan hubungan antara kuat tekan dan kuat tarik digunakan Persamaan 1 dan Persamaan 2.

$\boldsymbol{f}_{\boldsymbol{c t}}=\boldsymbol{a} \times \sqrt{\boldsymbol{f}^{\prime}} \quad \mathrm{MPa}$

$\sum_{i=0}^{3}\left(a X_{i}-Y_{i} \sqrt{X_{i}}\right)=0$

Pada penelitian ini didapatkan data $X_{i}$ sebagai hasil dari pengujian kuat tekan dan $Y_{i}$ didapat dari hasil pengujian kuat tarik. Data $X_{i}$ dan $Y_{i}$ pada tiap sambungan dapat dilihat pada Tabel 8,9 dan Tabel 10.

Tabel 7. Perbandingan Kuat Tekan dan Kuat Tarik

\begin{tabular}{|l|l|l|l|l|l|l|l|l|l|l|}
\hline Kode & \multicolumn{2}{|l|}{$\begin{array}{l}\text { Kuat tekan BK } \\
\text { rata-rata }\end{array}$} & \multicolumn{2}{l}{$\begin{array}{l}\text { Kuat tekan } \\
\text { BG rata-rata }\end{array}$} & $\begin{array}{l}\text { Kuat tarik } \\
\text { langsung } \\
\text { rata-rata }\end{array}$ & $\begin{array}{l}\text { Kuat } \\
\text { lentur } \\
\text { rata }\end{array}$ & \multicolumn{2}{l|}{$\begin{array}{l}\text { tarik } \\
\text { rata- }\end{array}$} & $\begin{array}{l}\text { Kuat } \\
\text { cabut tarik } \\
\text { rata }\end{array}$ \\
\hline & $(\mathrm{MPa})$ & $(\%)$ & $(\mathrm{MPa})$ & $(\%)$ & $(\mathrm{MPa})$ & $(\%)$ & $(\mathrm{MPa})$ & $(\%)$ & $(\mathrm{MPa})$ & $(\%)$ \\
\hline BG-BG & & & 31.49 & 100 & 2.38 & 7.56 & 4.56 & 14.48 & 1.62 & 5.14 \\
\hline BK-BG & 31.58 & 100.29 & 31.49 & 100 & 1.99 & 6.32 & 3.46 & 10.99 & 1.39 & 4.41 \\
\hline BK-BK & 31.58 & 100 & & & 1.59 & 5.03 & 2.76 & 8.74 & 0.93 & 2.94 \\
\hline
\end{tabular}


Tabel 8. Data $X_{i}$ dan $Y_{i}$ dari Hasil Pengujian Sambungan BG-BG

\begin{tabular}{|l|l|l|l|l|}
\hline \multirow{2}{*}{ No } & \multirow{2}{*}{$f_{c}^{\prime}$ Tekan } & \multicolumn{3}{|c|}{$\left(Y_{i}\right)$ (MPa) } \\
\cline { 3 - 5 } & $\left(X_{i}\right)$ (MPa) & $\begin{array}{c}f_{c t} \\
\text { langsung }\end{array}$ & $\begin{array}{c}f_{c t} \\
\text { lentur }\end{array}$ & $\begin{array}{c}f_{c t} \\
\text { cabut }\end{array}$ \\
\hline $\mathbf{1}$ & 31.68 & 2.42 & 4.46 & 1.76 \\
\hline $\mathbf{2}$ & 32.24 & 2.45 & 4.91 & 1.80 \\
\hline $\mathbf{3}$ & 30.55 & 2.26 & 4.30 & 1.66 \\
\hline
\end{tabular}

Tabel 9. Data $X_{i}$ dan $Y_{i}$ dari Hasil Pengujian Sambungan BK-BG

\begin{tabular}{|l|l|l|l|l|}
\hline \multirow{2}{*}{ No } & \multirow{2}{*}{$f_{c}^{\prime}{ }_{c}$ Tekan } \\
& $\left(X_{i}\right)$ (MPa) & \multicolumn{3}{|c|}{$\left(Y_{i}\right)$ (MPa) } \\
\cline { 3 - 5 } & & langsung & $\begin{array}{c}f_{c t} \\
\text { lentur }\end{array}$ & $\begin{array}{c}f_{c t} \\
\text { cabut }\end{array}$ \\
\hline $\mathbf{1}$ & 31.11 & 1.85 & 3.36 & 1.46 \\
\hline $\mathbf{2}$ & 32.52 & 2.12 & 3.46 & 1.42 \\
\hline $\mathbf{3}$ & 31.49 & 1.98 & 3.57 & 1.46 \\
\hline
\end{tabular}

Tabel 10. Data $X_{i}$ dan $Y_{i}$ dari Hasil Pengujian Sambungan BK-BK

\begin{tabular}{|l|l|l|c|c|}
\hline \multirow{2}{*}{ No } & \multirow{2}{*}{$f^{\prime}{ }_{c}$ Tekan } & \multicolumn{3}{|c|}{$\left(Y_{i}\right)$ (MPa) } \\
\cline { 3 - 5 } & $\left(X_{i}\right)$ (MPa) & $\begin{array}{c}f_{c t} \\
\text { langsung }\end{array}$ & $\begin{array}{c}f_{c t} \\
\text { lentur }\end{array}$ & $\begin{array}{c}f_{c t} \\
\text { cabut }\end{array}$ \\
\hline $\mathbf{1}$ & 31.11 & 1.67 & 2.37 & 0.93 \\
\hline $\mathbf{2}$ & 28.28 & 1.63 & 2.86 & 0.00 \\
\hline $\mathbf{3}$ & 33.94 & 1.47 & 3.05 & 0.00 \\
\hline
\end{tabular}

Contoh perhitungan koefisien persamaan kuat tarik langsung pada sambungan BG-BG sebagai berikut :

$\left(a X_{0}-Y_{0} \sqrt{X_{0}}\right)+\left(a X_{1}-Y_{1} \sqrt{X_{1}}\right)+\left(a X_{2}-\right.$ $\left.Y_{2} \sqrt{X_{2}}\right)+\left(a X_{3}-Y_{3} \sqrt{X_{3}}\right)=0$

$(a * 0-0 \sqrt{0})+(a * 31,68-2,42 *$

$\sqrt{31,68})+(a * 32,24-2,45 \sqrt{32,24})+(a *$

$30,55-2,26 * \sqrt{30,55})=0$

$94,47 * a-40,0233=0$

$a=\frac{40,0233}{94,47}=0,42$

Sehingga persamaan kuat tarik langsung pada sambungan BG-BG menjadi: $\boldsymbol{f}_{c t}=\mathbf{0 . 4 2} \sqrt{\boldsymbol{f}^{\prime}{ }_{c}} \mathrm{MPa}$. Hubungan kuat tekan dan kuat tarik pada tiap sambungan ditampilkan pada Tabel 11.

Tabel 11. Hubungan Kuat Tekan dan Kuat Tarik pada Tiap Sambungan

\begin{tabular}{|l|c|c|c|}
\hline \multirow{2}{*}{$\begin{array}{l}\text { Jenis } \\
\text { Sambungan }\end{array}$} & \multicolumn{3}{|c|}{ Kuat Tarik (MPa) } \\
\cline { 2 - 4 } & $\begin{array}{c}f_{c t} \\
\text { langsung }\end{array}$ & $\begin{array}{c}f_{c t} \\
\text { lentur }\end{array}$ & $\begin{array}{c}f_{c t} \\
\text { cabut }\end{array}$ \\
\hline BG-BG & $0.42 \sqrt{f^{\prime}{ }_{c}}$ & $0.81 \sqrt{f^{\prime}}$ & $0.31 \sqrt{f^{\prime}}$ \\
\hline BK-BG & $0.35 \sqrt{f^{\prime}}{ }_{c}$ & $0.62 \sqrt{f^{\prime}}$ & $0.26 \sqrt{f^{\prime}}$ \\
\hline BK-BK & $0,28 \sqrt{f^{\prime}}$ & $0,49 \sqrt{f^{\prime}}{ }_{c}$ & $0,17 \sqrt{f^{\prime}}$ \\
\hline
\end{tabular}

Berdasarkan Tabel 11. semua persamaan hubungan kuat tekan dan kuat tarik berada di dalam batas standar yang ada, kecuali untuk kuat tarik cabut sambungan BKBK yang memiliki nilai lebih kecil dari standar dan kuat tarik lentur sambungan BG-BG yang memiliki nilai lebih besar dari standar.

Pada pengujian kuat tarik langsung dan kuat tarik tidak langsung/ lentur semua sampel mengalami keruntuhan pada sambungan antar beton, sedangkan pada uji cabut sebagian benda uji mengalami keruntuhan di sambungan beton dan sebagian mengalami keruntuhan di beton SCGC. Lokasi keruntuhan pada benda uji ditunjukkan dalam Gambar 9 , Gambar 10 dan Gambar 11.

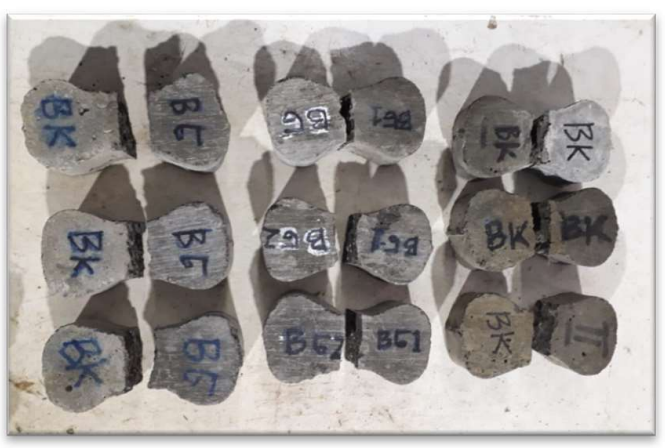

Gambar 9. Keruntuhan sampel Uji Tarik Langsung 


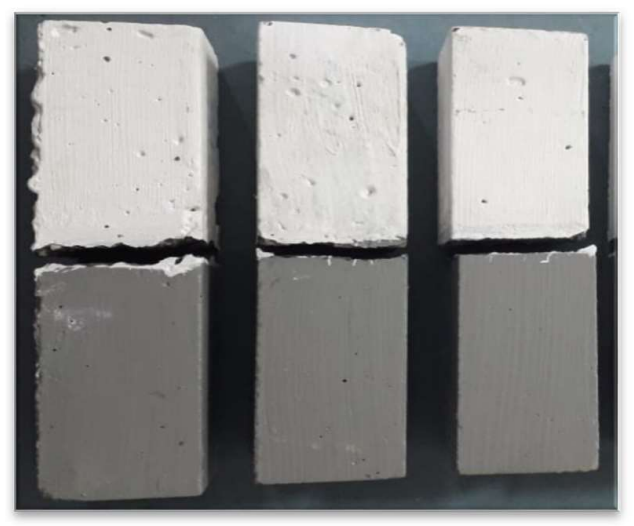

Gambar 10. Keruntuhan sampel Uji Tarik Lentur

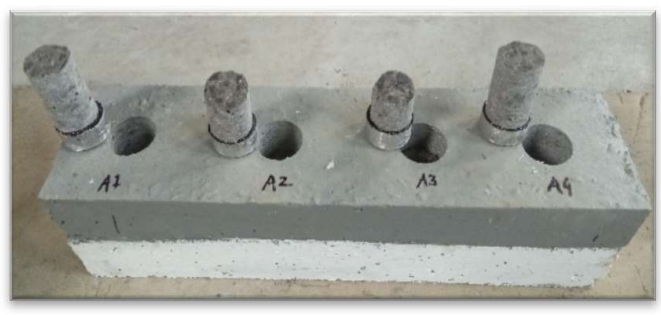

Gambar 11. Keruntuhan pada Benda Uji Tarik Cabut

\section{SIMPULAN}

Berdasarkan hasil analisa terhadap beban maksimum yang mampu diterima benda uji pada tiap variasi sambungan dapat diperoleh kesimpulan bahwa nilai kuat tarik terbesar pada ketiga metode pengujian terjadi pada sambungan BG-BG, disusul sambungan BK-BG, dan sambungan BK-BK.

Perbandingan kekuatan sambungan pada BG-BG : BK-BG : BK-BK yaitu $1: 0.84$ : 0.67 untuk kuat tarik langsung, $1: 0.76: 0.6$ untuk kuat tarik lentur, dan $1: 0.86: 0.57$ untuk kuat tarik cabut.

Secara umum sampel pada ketiga pengujian tarik mengalami keruntuhan pada sambungan antara beton lama dan beton baru. Dilihat dari hasil pengujian kuat lekat dengan ketiga metode tersebut dapat disimpulkan bahwa sambungan BG-BG dan BK-BG mempunyai nilai yang lebih besar daripada pada sambungan BK-BK, hal tersebut menunjukkan bahwa beton geopolimer SCGC mempunyai kuat lekat yang baik untuk dapat diaplikasikan dalam perbaikan struktur beton.

\section{DAFTAR PUSTAKA}

ACl Comitte 318. 1990. Building Code Requirements for Structural Concrete. American Concrete Institute.

Al Faridy, R. dan Ninda Z. A. 2019. Penelitian Beton Geopolimer dengan Karakteristik Workability yang Terbaik. Universitas Diponegoro.

ASTM C307. 2003. Standard Test Method for Tensile Strength of Chemical-Resistant Mortar, Grouts, and Monolithic Surfacings. ASTM International. West Conshohocken.

ASTM C1583. 2013. Standard Test Method for Tensile Strength of Concrete Surfaces and The Bond Strenght or Tensile Strength of Concrete Repair and Overlay Materials by Direct Tention (Pull-Off Method). ASTM International. West Conshohocken.

ASTM C33. 2008. Standard Spesification for Concrete Aggregates. ASTM International. West Conshohocken.

ASTM C40. 2004. Standard Test Method for Organic Impurities in Fine Aggregates for Concrete. ASTM International. West Conshohocken.

British Standard Institution. 1987. British Standard Code of Practice for Design of Concrete Structures for Retaining Aqueous Liquids. BS 8007.

EFNARC. 2005. The European Guidelines for Self-Compacting Concrete. EFNARC. United Kingdom.

Departemen Pekerjaan Umum. 1971. Peraturan Beton Bertulang Indonesia. Departemen Pekerjaan Umum. Jakarta.

Dipohosodo, I. 1999. Struktur Beton Bertulang Berdasarkan SK SNI T-15-1991-03. PT. GRAMEDIA: Jakarta.

Pd T-07-2005-B. 2005. Pelaksanaan Pekerjaan Beton untuk Jalan dan Jembatan. Departemen Pekerjaan Umum.

Qomaruddin, M. dan Sudarno. 2019. The study of laminate concrete between geopolymer and conventional. Journal of Physics: Conference Series 1363. https://doi.org/10.1088/1742-6596/1363/ 1/012011. 
Raphael J. M. 1984. Tensile Strenght of Concrete. Journal of The American Concrete Institute 81 (2), 158-165.

Selim P. 2008. Experimental Investigation of Tensile Behavior of High Strength Concrete Indian. Journal of Engineering and Materials Science 15 (6), 467-472.

SNI 03-1737-1989. 1989. Tata Cara Pelaksanaan Lapis Aspal Beton (LASTON) Untuk Jalan Raya. Badan Standardisasi Nasional. Jakarta.

SNI 03-2847-2013. 2013. Persyaratan Beton Struktural untuk Bangunan Gedung. Badan Standardisasi Nasional. Jakarta.

SNI 03-4154-2014. 2014. Metode Pengujian Kuat Lentur Beton dengan Balok Uji Sederhana yang Dibebani Terpusat Langsung. Badan Standardisasi Nasional. Jakarta.

SNI T-15-1991-03. 1991. Tata Cara Perhitungan Struktur Beton untuk Bangunan Gedung. Badan Standardisasi Nasional. Jakarta.

Triwiyono, A. 1998. Evaluasi Kinerja dan Perkuatan Struktur Gedung Guna Alih Fungsi Bangunan. Forum Teknik Sipil No. XVIII.

Tudjono, S., Han A. L., dan Hidayat, B. A. 2015. An Experimental Study to the Influence of Fiber Reinforced Polymer (FRP) Confinement on Beams Subjected to Bending and Shear. Procedia Engineering. Vol 125. 